\title{
PENERAPAN METODE REGRESI LOGISTIK ORDINAL BAYESIAN UNTUK MENENTUKAN TINGKAT PARTISIPASI POLITIK MASYARAKAT KOTA PADANG
}

\author{
ANGGUN CITRA DELIMA, FERRA YANUAR, HAZMIRA YOZZA \\ Program Studi S1 Matematika, \\ Fakultas Matematika dan Ilmu Pengetahuan Alam, Universitas Andalas, \\ Kampus UNAND Limau Manis Padang, Indonesia. \\ email : angguncitradelima@gmail.com
}

\begin{abstract}
Abstrak. Penelitian ini bertujuan untuk mengetahui bagaimana model tingkat partisipasi politik masyarakat kota Padang. Untuk memenuhi tujuan tersebut digunakan metode regresi logistik ordinal dan metode Bayesian. Metode Bayesian merupakan salah satu teknik estimasi parameter yang menggabungkan fungsi likelihood dan distribusi prior sehingga diperoleh distribusi posterior yang akan digunakan untuk menduga parameter model. Dari penelitian ini diperoleh dua peubah bebas yang berpengaruh signifikan terhadap tingkat partisipasi politik masyarakat kota Padang yaitu tingkat kepercayaan masyarakat dan keterlibatan politik masyarakat. Dengan nilai Odds ratio untuk tingkat kepercayaan masyarakat sebesar 0,942 dan untuk keterlibatan politik masyarakat sebesar 1,101 .
\end{abstract}

Kata Kunci: Metode Bayesian, Odds ratio, Regresi Logistik Ordinal

\section{Pendahuluan}

Indonesia merupakan suatu negara yang menganut sistem demokrasi. Dengan sistem demokrasi berarti keikutsertaan masyarakat dalam setiap pengambilan keputusan akan sangat mempengaruhi kondisi negara. Pemilu merupakan suatu cara untuk menentukan bagaimana suatu pemerintahan dapat dibentuk secara demokratis. Di Indonesia pemilihan umum dilaksanakan setiap sekali lima tahun untuk memilih anggota legislatif yaitu DPR dan DPRD dan untuk memilih anggota eksekutif yaitu Presiden, Gubernur, dan Bupati/Walikota.

Pada tanggal 27 Juni 2018, telah dilakukan pemilihan kepala daerah di kota Padang. Berdasarkan surat keputusan komisi pemilihan umum kota Padang Nomor 101/HK.03.1-Kpt/1371/KPU-Kot/VII/2018 diketahui bahwa dari 11 kecamatan yang ada di kota Padang terdapat 1600 TPS yang tersebar dengan jumlah daftar pemilih tetap (DPT) sebanyak 535.265 orang. Dari calon pemilih tersebut, hanya 331.837 orang atau sekitar 62 persen masyarakat yang menggunakan hak pilih dan kewajibannya. Ini berarti hanya sebagian dari masyarakat kota Padang yang memiliki kesadaran untuk berpartisipasi dalam bidang politik, padahal keikutsertaan 
masyarakat tersebut sangat mempengaruhi kehidupan kota Padang ke depannya. Oleh karena itu, perlu diketahui apa saja faktor yang dapat mempengaruhi model tingkat partisipasi politik masyarakat kota Padang.

Salah satu teknik analisis yang cocok digunakan adalah analisis regresi. Karena pada penelitian ini, peubah tak bebas $Y$ adalah peubah kategori yang terdiri dari lima kategori. Sehingga digunakan analisis regresi logistik ordinal. Salah satu metode yang dapat digunakan untuk menduga parameter dalam analisis regresi adalah dengan menggunakan metode Bayesian, sehingga metode regresi logistik ordinal Bayesian tersebut diaplikasikan untuk membuat model tingkal partisipasi masyarakat kota Padang. Metode Bayesian ini memanfaatkan informasi dari data sampel dan informasi dari sebaran parameter yang dinyatakan dalam bentuk sebaran prior. Informasi data sampel selanjutnya digabung dengan distribusi prior untuk mendapatkan sebaran posterior yang pada tahap akhir digunakan untuk mendapatkan penduga parameter. Pada artikel ini, metode regresi logistik ordinal Bayesian tersebut diaplikasikan untuk membuat model tingkat partisipasi politik masyarakat kota Padang.

\section{Landasan Teori}

\subsection{Regresi Logistik}

Analisis regresi logistik merupakan salah satu analisis regresi yang digunakan jika peubah tak bebasnya merupakan peubah yang memiliki dua kemungkinan hasil, yaitu $Y=1$ (sukses) dan $Y=0$ (gagal) dengan peluang masing-masing $p$ dan $q=1-p$.

Bentuk umum dari model regresi logistik adalah.

$$
p_{i}=\frac{\exp \left(\beta_{0}+\beta_{1} X_{i_{1}}+\beta_{2} X_{i_{2}}+\cdots+\beta_{k} X_{i_{k}}\right)}{1+\exp \left(\beta_{0}+\beta_{1} X_{i_{1}}+\beta 2 X_{i_{2}}+\cdots+\beta_{k} X_{i_{k}}\right)} .
$$

Untuk membentuk model regresi logistik maka dilakukan transformasi logit terlebih dahulu terhadap persamaan (2.1) sehingga diperoleh:

$$
\operatorname{logit}\left(p_{i}\right)=\beta_{0}+\beta_{1} X_{i_{1}}+\beta_{2} X_{i_{2}}+\cdots+\beta_{k} X_{i_{k}} .
$$

\subsection{Regresi Logistik Ordinal}

Regresi logistik ordinal merupakan salah satu analisis regresi yang digunakan untuk menganalisa hubungan antara variabel bebas dan variabel tak bebas, dimana variabel tak bebas adalah variabel kategorik yang berskala ordinal. Model logistik untuk data dengan peubah tak bebas berskala ordinal ini sering pula disebut dengan model logit kumulatif [3].

Secara matematis model logit kumulatif dapat dinyatakan sebagai:

$$
\operatorname{logit}\left(p_{i}\right)=\ln \left(\frac{P(Y \leq j \mid x)}{P(Y>j \mid x)}\right)
$$

Peluang kumulatif $P(Y \leq j \mid k)$ didefinisikan sebagai berikut:

$$
P(Y \leq j \mid x)=\ln \frac{1}{1+\exp \left(-\left(a_{j}+\sum_{t=1}^{k} \beta_{t} X_{t}\right)\right.},
$$


dimana $j=1,2, \cdots, J$ adalah kategori peubah tak bebas dan $k$ adalah banyaknya peubah bebas.

Persamaan ini bersifat nonlinier dalam parameter maka diperlukan proses transformasi logit terlebih dahulu terhadap persamaan (2.4) untuk membentuk model regresi logistik yang bertujuan untuk mempertahankan struktur linier dari parameter-parameternya, sehingga diperoleh persamaan:

$$
\operatorname{logit}\left(p_{j}\right)=\left(a_{j}+\sum_{t=1}^{k} \beta_{t} X_{t}\right)
$$

Jika terdapat $J$ kategori peubah tak bebas dimana $j=1,2, \cdots, J$ maka peluang kumulatif kategori ke- $j$ dari persamaan tersebut dapat ditulis sebagai berikut:

$$
P(Y \leq j \mid x)=p_{1}(x)+p_{2}(x)+\cdots+p_{j}(x),
$$

dengan $p_{j}(x)=P(Y=j \mid x)$.

\subsection{Interpretasi Parameter Regresi Logistik}

Misalkan diketahui model regresi logistik dengan $k$ peubah bebas sebagai berikut:

$$
\frac{p_{i}}{1-p_{i}}=\exp \left(\alpha_{0}+\beta_{1} X_{i j}+\beta_{2} X_{i 2}+\cdots+\beta k X_{i k}\right) .
$$

Ruas kiri dari persamaan (2.7) merupakan perbandingan antara peluang berhasil $p_{i}$ dengan peluang gagal $1-p_{i}$ yang disebut odds, sedangkan perbandingan nilai odds antara dua individu disebut odds ratio.

Berikutnya akan ditentukan nilai odds untuk regresi logistik ordinal. Untuk suatu kategori $j$ dari peubah tak bebas $Y$ nilai dari odds didefinisikan sebagai:

$$
O d d s=\frac{P\left(Y \leq j \mid x_{1}\right)}{P\left(Y>j \mid x_{1}\right)}
$$

Jika peubah bebas merupakan peubah kategori maka untuk menginterpretasikan seberapa besar peubah bebas berpengaruh terhadap peubah tak bebas dilakukan dengan cara membandingkan nilai odds dari salah satu peubah bebas tersebut dengan nilai yang menjadi referensinya, sedangkan untuk peubah bebas kontinu interpretasinya adalah setiap kenaikan nilai sebesar satu satuan pada peubah bebas akan mengakibatkan perubahan nilai odds terjadinya $Y=j \operatorname{sebesar} \exp \left(\beta_{j}\right)$.

\subsection{Metode Logistik Bayesian}

Metode Bayesian dapat digunakan untuk menduga parameter dalam analisis regresi dengan langkah-langkah sebagai berikut [5], Pertama, menentukan fungsi likelihood dari data, dalam hal ini fungsi likelihood dari peubah tak bebas $Y$. Selanjutnya, menentukan distribusi prior dari parameter, dalam hal ini adalah parameter regresi $\beta$ dan parameter lainnya. Kemudian yang terakhir menentukan distribusi posterior dari parameter regresi yang merupakan hasil kali dari fungsi likelihood dengan distribusi prior-nya. 


\subsubsection{Fungsi Likelihood}

Definisi 2.1. [1] Fungsi kepekatan peluang bersama dari $n$ peubah acak $X_{1}, X_{2}$, $\cdots, X_{n}$ yang dihitung pada $x_{1}, x_{2}, \cdots, x_{n}$ dinyatakan oleh $f\left(x_{1}, x_{2}, \cdots, x_{n ; \beta}\right)$ disebut sebagai fungsi likelihood. Untuk $x_{1}, x_{2}, \cdots, x_{n}$ tetap, fungsi likelihood adalah fungsi dari parameter $\beta$ yang dinotasikan dengan $L(\beta)$. Jika $X_{1}, X_{2}, \cdots, X_{n}$ merupakan contoh acak dari $f(x ; \beta)$ maka:

$$
L(\beta)=f\left(x_{1} ; \beta\right) f\left(x_{2} ; \beta\right) \cdots f\left(x_{n} ; \beta\right)
$$

dengan $\beta$ adalah parameter yang tidak diketahui.

\subsubsection{Distribusi Prior}

Terdapat beberapa tipe distribusi prior, berkaitan dengan bentuk distribusi hasil identifikasi pola datanya distribusi prior dibagi menjadi dua bagian yaitu [2]:

(1) Distribusi prior konjugat,

(2) Distribusi prior non-konjugat.

Berkaitan dengan informasi yang terkait dengan penentuan masing-masing parameter, distribusi prior dibagi menjadi dua bagian yaitu [2]:

(1) Distribusi prior informatif,

(2) Distribusi prior non-informatif.

\subsubsection{Distribusi Posterior}

Definisi 2.2. [5] Fungsi kepekatan peluang posterior dari $\beta$ jika diketahui sampel pengamatan $x_{1}, x_{2}, \cdots, x_{n}$ adalah:

$$
f(x \mid \beta)=\frac{f(x \mid \beta) f(\beta)}{\int f(x \mid \beta) f(\beta) d \beta} \propto f(x \mid \beta) f(\beta) .
$$

\subsubsection{Markov Chain Monte Carlo (MCMC)}

Markov Chain Monte Carlo (MCMC) adalah suatu metode untuk menentukan nilai parameter dari suatu integrasi analitik yang sulit menggunakan teknik simulasi numerik. Terdapat dua macam metode MCMC yang sering digunakan yaitu metode Gibbs Sampler dan Metropolis-Hastings. Metode Gibbs Sampler merupakan teknik yang sering dipakai oleh pengguna metode Bayes [5].

\subsubsection{Uji Kekonvergenan}

Pada metode Bayesian terdapat beberapa cara untuk melihat kekonvergenan parameter model yaitu Trace plot, Autocorrelation plot, Quantiles plot, Density plot atau dengan membandingkan nilai Monte Carlo Error (MC Error) dengan standar deviasi parameter model. 


\subsubsection{Deviance Information Criterion (DIC)}

Pemilihan model terbaik pada Bayesian dapat dilakukan dengan membandingkan nilai DIC dengan menggunakan software WinBUGS. Perhitungan DIC ini dapat dilakukan untuk banyak model, model dengan nilai DIC terkecil adalah model pendugaan terbaik [5].

Statistik DIC pada Bayesian MCMC:

$$
D I C=\bar{D}+p D=\bar{D}+2 p D=2 \bar{D}-\bar{D} .
$$

\section{Data dan Hasil}

Data yang digunakan dalam penelitian ini adalah data sekunder yang diperoleh dari penelitian sebelumnya yaitu tentang teknik Structural Equation Modeling (SEM) dalam memodelkan tingkat partisipasi politik di kota Padang pada tahun 2018 yang melibatkan 150 responden [2].

\subsection{Pembentukan Model Terbaik}

Estimasi parameter dengan metode regresi logistik Bayesian dilakukan menggunakan bantuan software WinBUGS 14. Hasil estimasi parameter dapat dilihat pada Tabel 1.

Tabel 1. Hasil Estimasi Parameter Model

\begin{tabular}{|l|c|l|l|l|l|}
\hline Parameter & Mean & $\begin{array}{l}\text { Standar } \\
\text { Deviasi }\end{array}$ & $\begin{array}{l}\mathbf{5} \text { persen } \\
\text { Standar } \\
\text { Deviasi }\end{array}$ & $\begin{array}{l}\text { MC } \\
\text { Error }\end{array}$ & Keterangan \\
\hline$\alpha_{1}$ & $-5,573$ & 1,745 & 0,08725 & 0,08602 & Konvergen \\
$\alpha_{2}$ & $-3,859$ & 1,637 & 0,08185 & 0,07885 & Konvergen \\
$\alpha_{3}$ & $-0,749$ & 1,597 & 0,07985 & 0,07578 & Konvergen \\
$\alpha_{4}$ & 4,570 & 2,039 & 0,10195 & 0,07521 & Konvergen \\
$\beta_{1}$ & $-0,066$ & 0,029 & 0,001467 & 0,001246 & Konvergen \\
$\beta_{2}$ & $-0,021$ & 0,057 & 0,002858 & 0,002481 & Konvergen \\
$\beta_{3}$ & 0,029 & 0,072 & 0,003642 & 0,002948 & Konvergen \\
$\beta_{4}$ & 0,093 & 0,051 & 0,002556 & 0,001623 & Konvergen \\
\hline
\end{tabular}

Uji kekonvergenan dilakukan dengan menggunakan Trace plot, Autocorrelation plot, Quantiles plot, Density plot, dan MC Error dari masing-masing parameter. Dengan demikian, berdasarkan pemeriksaan konvergensi dapat disimpulkan bahwa model dugaan telah memenuhi kriteria kekonvergenan yang berarti model tersebut dapat diterima.

Pengujian signifikansi parameter bertujuan untuk memeriksa apakah peubahpeubah bebas mempunyai pengaruh yang signifikan terhadap peubah tak bebas. Adapun hasil pengujian peubah bebas dapat dilihat pada Tabel 2.

Nilai $\chi^{2}$ yang diperoleh dari tabel $\chi^{2}$ dengan nilai $\alpha=0,1$ dan derajat bebas $=1$ adalah sebesar 2,706 sehingga dapat dilihat pada Tabel 2 bahwa hanya terdapat 2 peubah bebas yang memiliki nilai $W$ yang lebih besar dari nilai $\chi^{2}$ yaitu peubah 
Tabel 2. Hasil Pengujian Variabel Bebas

\begin{tabular}{|l|c|l|l|l|}
\hline Parameter & Mean & Standar Deviasi & Statistik W & Keterangan \\
\hline$\beta_{1}$ & $-0,066$ & 0,029 & 5,027 & Signifikan \\
$\beta_{2}$ & $-0,021$ & 0,057 & 0,130 & Tidak Signifikan \\
$\beta_{3}$ & 0,029 & 0,072 & 0,163 & Tidak Signifikan \\
$\beta_{4}$ & 0,093 & 0,051 & 3,317 & Signifikan \\
\hline
\end{tabular}

$X_{1}$ (tingkat kepercayaan) dan $X_{4}$ (keterlibatan politik masyarakat) sehingga dapat disimpulkan bahwa hanya peubah $X_{1}$ (tingkat kepercayaan) dan $X_{4}$ (keterlibatan politik masyarakat) yang berpengaruh signifikan terhadap peubah tak bebas $Y$ (tingkat partisipasi politik).

Peubah-peubah bebas yang signifikan kembali di estimasi mengggunakan metode regresi logistik Bayesian untuk memodelkan tingkat partisipasi politik masyarakat di Kota Padang. Hasil estimasi parameter dapat dilihat pada Tabel 3.

Tabel 3. Hasil Estimasi Parameter Model

\begin{tabular}{|l|c|l|l|l|l|}
\hline Parameter & Mean & $\begin{array}{l}\text { Standar } \\
\text { Deviasi }\end{array}$ & $\begin{array}{l}\mathbf{5} \text { persen } \\
\text { Standar } \\
\text { Deviasi }\end{array}$ & $\begin{array}{l}\text { MC } \\
\text { Error }\end{array}$ & Keterangan \\
\hline$\alpha_{1}$ & $-5,129$ & 1,510 & 0,0755 & 0,07232 & Konvergen \\
$\alpha_{2}$ & $-3,436$ & 1,371 & 0,06855 & 0,06373 & Konvergen \\
$\alpha_{3}$ & $-0,363$ & 1,335 & 0,06675 & 0,06078 & Konvergen \\
$\alpha_{4}$ & 4,945 & 1,815 & 0,09075 & 0,05782 & Konvergen \\
$\beta_{1}$ & $-0,059$ & 0,028 & 0,001409 & 0,001312 & Konvergen \\
$\beta_{4}$ & 0,096 & 0,041 & 0,002033 & 0,001171 & Konvergen \\
\hline
\end{tabular}

Dengan demikian, berdasarkan pemeriksaan konvergensi dapat disimpulkan bahwa model dugaan telah memenuhi kriteria kekonvergenan yang berarti model tersebut dapat diterima.

Hasil pengujian peubah bebas dapat dilihat pada Tabel 4 .

Tabel 4. Hasil Pengujian Variabel Bebas

\begin{tabular}{|l|c|l|l|l|}
\hline Parameter & Mean & Standar Deviasi & Statistik W & Keterangan \\
\hline$\beta_{1}$ & $-0,059$ & 0,028 & 4,476 & Signifikan \\
$\beta_{4}$ & 0,096 & 0,041 & 5,619 & Signifikan \\
\hline
\end{tabular}

Berdasarkan Tabel 4 dapat diketahui bahwa nilai W untuk peubah $X_{1}$ (tingkat kepercayaan) dan $X_{4}$ (keterlibatan politik masyarakat) telah menunjukkan nilai yang lebih besar dari nilai $\chi^{2}$ sehingga dapat disimpulkan bahwa kedua peubah bebas tersebut berpengaruh signifikan terhadap peubah tak bebas.

Diperoleh model tingkat partisipasi politik masyarakat kota Padang sebagai 
berikut:

$$
\begin{aligned}
& \operatorname{logitp}_{1}(x)=-5,129+(-0,059) x_{1}+0,096 x_{4}, \\
& \operatorname{logitp}_{2}(x)=-3,436+(-0,059) x_{1}+0,096 x_{4}, \\
& \operatorname{logitp}_{3}(x)=-0,363+(-0,059) x_{1}+0,096 x_{4}, \\
& \operatorname{logitp}_{4}(x)=4,945+(-0,059) x_{1}+0,096 x_{4} .
\end{aligned}
$$

\subsection{Interpretasi Parameter Model}

Untuk menginterpretasikan seberapa besar peubah bebas berpengaruh terhadap peubah tak bebas (tingkat partisipasi politik) maka digunakan nilai odds ratio yang nilainya dapat dilihat pada Tabel 5 .

Tabel 5. Hasil Pengujian Variabel Bebas

\begin{tabular}{|l|c|l|}
\hline Parameter & Estimasi $(\beta)$ & $\begin{array}{l}\text { Odds Ratio }= \\
\exp (\beta)\end{array}$ \\
\hline$\beta_{1}$ (tingkat kepercayaan) & $-0,059$ & 0,942 \\
$\beta_{4}$ (keterlibatan politik masyarakat) & 0,096 & 1,101 \\
\hline
\end{tabular}

Berdasarkan Tabel 5 nilai odd ratio untuk peubah tingkat kepercayaan adalah sebesar 0,942 yang berarti resiko keaktifan tingkat partisipasi politik masyarakat akan menurun sebesar 0,942 kali setiap kenaikan 1 poin peubah tingkat kepercayaan dengan peubah lain dianggap konstan, sedangkan kenaikan 1 poin peubah keterlibatan politik masyarakat akan mengakibatkan resiko keaktifan tingkat partisipasi politik masyarakat naik sebesar 1,101 kali dengan menganggap peubah lain konstan.

\section{Kesimpulan}

Dari analisis data dengan menggunakan empat peubah bebas yang diduga menjadi faktor yang mempengaruhi tingkat partisipasi politik masyarakat kota Padang $(Y)$ yaitu tingkat kepercayaan masyarakat $\left(X_{1}\right)$, kesadaran politik masyarakat $\left(X_{2}\right)$, pengetahuan politik masyarakat $\left(X_{3}\right)$, serta keterlibatan politik masyarakat $\left(X_{4}\right)$ diperoleh dua peubah bebas yang berpengaruh signifikan terhadap tingkat partisipasi politik masyarakat kota Padang yaitu tingkat kepercayaan masyarakat $\left(X_{1}\right)$ dan keterlibatan politik masyarakat $\left(X_{4}\right)$. Diperoleh model tingkat partisipasi politik masyarakat kota Padang sebagai berikut:

$$
\begin{aligned}
& \operatorname{logitp}_{1}(x)=-5,129+(-0,059) x_{1}+0,096 x_{4}, \\
& \operatorname{logitp}_{2}(x)=-3,436+(-0,059) x_{1}+0,096 x_{4}, \\
& \operatorname{logitp}_{3}(x)=-0,363+(-0,059) x_{1}+0,096 x_{4}, \\
& \operatorname{logitp}_{4}(x)=4,945+(-0,059) x_{1}+0,096 x_{4} .
\end{aligned}
$$


8 Anggun Citra Delima dkk

\section{Daftar Pustaka}

[1] Amanda, L. 2018. Teknik Structural Equation Modeling (SEM) dalam memodelkan tingkat partisipasi politik masyarakat kota Padang. Skripsi pada jurusan Matematika FMIPA Universitas Andalas. Padang: tidak diterbitkan

[2] Bain, L.J dan Engelhardt, M.1992. Introduction to Probability and Mathematical Statistic Second Edition. California: Duxbury Press

[3] Hosmer, D.W. dan Lemeshow, S. 2000. Applied Logistic Regression. New York: John Wiley and Sons, Inc

[4] Muharisa, C. 2018. Simulation study of the using Bayesian quantile regression in non normal error. Jurnal Matematika Murni dan Aplikasi. Volume 5: $121-$ 126

[5] Ntzoufras, I. 2009. Bayesian Modelling Using WinBUGS. Ney Jersey: John Wiley and Sons,Inc 